\title{
PENERAPAN MEDIA CUPLIKAN FILM BERBANTUAN PINDAI KODE QR DALAM PEMBELAJARAN TEKS BIOGRAFI
}

\author{
Yani Septiani ${ }^{1}$ \\ SMKN 1 Simpang Rimba Bangka Selatan, ${ }^{1}$ yaniseptiani29@ gmail.com \\ Jamjam Sapaat ${ }^{2}$ \\ SMPN 1 Solokanjeruk Kabupaten Bandung, ${ }^{2}$ jamjamsapaat1992@gmail.com
}

\begin{abstract}
Abstrak
Penelitian ini dilatarbelakangi oleh kurangnya penggunaan beragam media pembelajaran yang mempengaruhi hasil belajar dan pemikiran siswa tingkat tinggi. Tujuan dari penelitian ini adalah untuk mengetahui efektivitas cuplikan film dengan aplikasi $Q R$-code dalam memahami teks biografi di SMKN 1 Simpang Rimba, Bangka Selatan. Teori yang mendasari adalah teori pendekatan pembelajaran dan media pembelajaran yang terkait dengan Higher Order Thinking Skill (HOTS). Metode penelitian ini menggunakan One-Shot Case Study. Data penelitian berupa data pretest dan posttest yaitu memahami teks biografi dalam tes formatif dengan pertanyaan dan kuesioner HOTS. Hasil penelitian adalah pengakuan cuplikan film dengan kode QR lebih efektif dalam belajar memahami teks biografi dan dapat membantu siswa untuk berpikir lebih tinggi atau berpikir kritis.
\end{abstract}

Kata kunci: pembelajaran teks biografi, media cuplikan film, pemindai kode QR, HOTS

\section{Abstract}

This research is motivated by the lack of varied use of instructional media that influences the learning outcomes and the high-level thinking of student. The purpose of this research is to determine the effectiveness of film footage with $Q R$ code application in understanding biographical text in SMKN 1 Simpang Rimba, South Bangka. The underlying theory is the theory of learning approaches and instructional media related to Higher Order Thinking Skill (HOTS). This research method uses One-Shot Case Study. The research data in the form of pretest and posttest data is understanding biographical text in formative test with HOTS questions and questionnaire. The result of research is the recognition of film footage with QR code more effective in learning to understand biographical text and it can help students to think higher or to think critically.

Keywords: learning biographical text, media of film footage, $Q R$ code scanner, HOTS 


\section{PENDAHULUAN}

Proses pembelajaran sangat bergantung pada komunikasi antara pendidik dan peserta didik. Hubungan tersebut akan menentukan motivasi peserta didik dalam mengikuti pembelajaran. Apabila hal tersebut telah berjalan dengan baik, peserta didik akan merasa nyaman dan senang dalam mengikuti setiap proses pembelajaran. Sehingga, tujuan pembelajaran akan tercapai serta hasil belajar sesuai harapan. Selain komunikasi, hal lain yang dapat mempengaruhi hasil belajar adalah media. Sebagaimana yang diungkapkan Azhar Arsyad (2003, hlm. 25) salah satu manfaat media pembelajaran adalah dapat meningkatkan dan mengarahkan perhatian anak sehingga dapat menimbulkan motivasi belajar, interaksi yang lebih langsung antara peserta didik dan lingkungannya, dan kemungkinan peserta didik untuk belajar sendiri-sendiri sesuai dengan kemampuan dan minatnya.

Realitas yang terjadi di lapangan khususnya pembelajaran Bahasa Indonesia, penulis sebagai pendidik yang mengampu mata pelajaran Bahasa Indonesia menemukan hal berkaitan dengan hasil belajar yang masih belum tinggi bahkan belum memenuhi angka KKM. Hal tersebut tercermin pada tempat penulis bekerja/mengajar yakni di SMK Negeri 1 Simpang Rimba, bahwa hasil USBN Bahasa Indonesia menunjukkan rerata 56,8 dengan angka KKM 55. Hal tersebut menunjukkan belum tingginya hasil belajar peserta didik dalam pembelajaran Bahasa Indonesia. Berdasarkan hasil observasi lapangan, komunikasi dengan stakeholder, serta diskusi dengan guru pengampu sebelumnya, bahwa metode dan media pembelajaran masih belum bervariatif, masih seputar metode praktik dan proyek. Hal tersebut tidak menutup kemungkinan menjadikan sebagian peserta didik merasakan kurang ketertarikan untuk mengikuti pembelajaran Bahasa Indonesia.

Selain itu, tidak semua materi dapat tersampaikan dengan optimal dengan metode belajar yang itu-itu saja. Tentulah hal tersebut sangat berpengaruh pada tingkat daya serap materi karena selera belajar yang kurang serta ketidakcocokkan metode belajar dengan jenis materi yang disampaikan. Apabila hal tersebut terus berulang, tujuan pembelajaran tidak akan tersampaikan dan hasil belajar pun tidak akan sesuai dengan harapan.

Pembelajaran abad ke-21 menuntut peserta didik untuk dapat berpikir tingkat tinggi atau berpikir kritis. Hal tersebut bertujuanan agar peserta didik sebagai generasi emas masa depan dapat terbiasa untuk memecahkan permasalahan yang tentu akan semakin kompleks di masa depam. Keterampilan berpikir tingkat tinggi dalam bahasa umum dikenal sebagai Higher Order Thinking Skill (HOTS)h

HOTS erat sekali dengan istilah Taksonomi Bloom. Taksonomi Bloom dianggap sebagai dasar bagi berpikir tingkat tinggi. Pemikiran ini didasarkan bahwa beberapa jenis pembelajaran memerlukan proses kognisi yang lebih dari pada yang lain, tetapi memiliki manfaat yang lebih umum. Menurut Pohl (2000) dalam Taksonomi Bloom revisi, 
kemampuan melibatkan analisis (C4), mengevaluasi (C5), dan mencipta (C6) dianggap berpikir tingkat tinggi. Hal tersebut memberikan tantangan pada para pendidik untuk dapat melaksanakan pembelajaran yang mengarah pada pembelajaran abad ke-21.

Uraian di atas memunculkan suatu gagasan kreatif sebagai pemecahan terhadap problematika yang terjadi di unit kerja penulis sekaligus untuk menjawab tantangan pembelajaran abad ke-21. Solusi alternatif tersebut berupa penerapan pendekatan pembelajaran yang selaras dengan materi/kompetensi dasar. Penulis menerap-kan pendekatan saintifik.

Pendekatan saintifik menurut Imas Kurniasih (2014, hlm. 29) adalah proses pembelajaran yang dirancang sedemikian rupa agar peserta didik secara aktif mengkonstruksikan konsep pembelajaran melalui tahapantahapan mengamati (untuk mengidentifikasi atau menemukan masalah), merumuskan masalah, mengajukan atau merumuskan hipotesis, mengumpulkan data dengan berbagai teknik, menganalisis data, menarik kesimpulan dan mengkomunikasikan konsep.

Sorot utama penulis dalam penelitian ini ialah penulis menerapkan media pembelajaran untuk mencapai efektivitas penyerapan materi yang dicapai dengan menggunakan media audiovisual berupa cuplikan film.

Menurut Sumantri dan Permana (2006, hlm. 161) menjelaskan bahwa media audiovisual merupakan media yang tidak hanya dapat dilihat atau dipandang tetapi juga media yang dapat didengar. Melalui media ini seseorang tidak dapat mendengar atau melihat saja, tetapi dapat melihat sekaligus mendengar sesuatu yang divisualisasikan. Dari penjelasan tersebut penulis memilih media audiovisual sebagai penunjang proses pembelajaran selain meningkatkan daya berpikir tingkat tinggi peserta didik, media tersebut dapat meningkatkan motivasi belajar dan menarik perhatian siswa adalah untuk mempermudah siswa dalam mengingat konsep lebih banyak, membantu siswa memahami konsep, serta menciptakan suasana belajar yang nyaman, kondusif serta menyenangkan dengan menggunakan media audiovisual.

Demi tercapainya tujuan secara optimal, faktor rasa keinginan peserta didik pun penulis perhatikan, yakni dengan adanya bentuk evaluasi untuk mengukur tercapainya kompetensi dasar dengan cara yang berbeda yakni berbantuan Kode QR. Kode QR termasuk salah satu jenis barcode dua dimensi. Kode QR mempunyai dua sisi yang berisi data.

Hal ini membuat kode QR banyak memuat informasi dibandingkan barcode. Kode QR, misalnya dapat menampung informasi URL, suatu website yang nantinya dapat diguna-kan pada majalah iklan atau media lainnya, sehingga ketika seorang pengguna telepon genggam berkamera dan memiliki aplikasi pembaca, kode QR dapat langsung memindai dan masuk ke website yang dimaksud tanpa perlu mengetikkan alamatnya. Kegu-naan lainnya misalnya, kode QR digunakan untuk menyimpan data teks mengenai informasi produk atau hal lain, SMS, atau informasi kontak yang mengandung nama, nomor 
telepon, dan alamat (Crompton, 2012).

Berdasarkan penjelasan di atas kode QR memiliki fungsi dalam memuat suatu informasi. Penulis mencoba untuk melakukan inovasi dalam proses pembelajaran dengan mengacu pada fungsi dari kode QR tersebut. Oleh karena itu, penulis memanfaatkan kode QR dalam pembelajaran. Kode QR tersebut diaplikasikan sebagai pengganti Lembar Kerja Siswa. Sehingga, peserta didik setelah mengikuti pembelajaran diminta untuk me-ngisi beberapa pertanyaan serta untuk mengukur pemahamannya terhadap kompetensi yangharus dicapai.

Selain untuk menunjang pada berpikir kritis sebagai karakteristik pembelajar abad ke-21, hal tersebut diharapkan dapat menunjang perkembangan zaman dalam pendidikan yakni pembelajaran 4.0 berbasis pembelajaran digital.

Penelitian ini bertujuan untuk memecahkan permasalahan berkaitan dengan hasil belajar Bahasa Indonesia, meningkatkan hasil belajar Bahasa Indonesia, menyosialisasikan pembelajaran berpikir tingkat tinggi sebagai pembelajar abad ke-21, serta untuk menyosialisasikan random sampling sehingga sampel dalam penelitian ini adalah kelas $\mathrm{X}$ Multimedia yang berjumlah 26 orang. Variabel bebas dalam penelitian ini adalah penerapan media audiovisual berbentyk cuplikan film berbantuan pindai kode QR pada pembelajaran teks biografi. Adapun variabel terikat dalam penelitian ini adalah hasil belajar peserta didik dengan indikator pengetahuan (prates dan pascates), sikap peserta didik saat pembelajaran, serta keterampilan peserta didik dalam mengungkapkan kembali.

Metode yang digunakan dalam penelitian ini adalah kuasi eksperimen dengan menggunakan desain One-Shot Case Study.

Menurut Sugiyono (2012, hlm. 74) One-Shot Case Study merupakan desain penelitian yang terdiri dari satu kelompok yang diberi treatment atau perlakuan yang kemudian mengobservasi hasil tersebut. Pada desain ini terdapat kegiatan prates atau tes awal yang dilakukan sebelum adanya perlakuan. Hal tersebut bertujuan untuk melihat keakuratan perlakuan yang diterapkan dengan melakukan postest setelah diterapkannya perlakuan sehingga perbandingan akan tampak. Adapun pembelajaran $\quad 4.0 \quad$ berbasisidikan penggambaran desain tersebut pembelajaran digital. Indonesia da tergambar sebagai berikut:

\section{METODE}

Penelitian ini dilakukan di SMK Negeri 1 Simpang Rimba, Bangka Selatan. Populasi dalam penelitian ini adalah peserta didik kelas X di SMK Negeri 1 Simpang Rimba yang berjumlah 49 orang. Sampel yang diguna-kan dalam penelitian ini diambil dengan teknik sample
Tabel Desain One-Shot Case Study

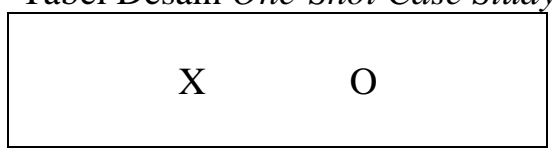

Sugiyono, 2012, hlm. 74

Keterangan:

$\mathrm{X}=$ treatment/perlakuan yang 
diberikan (dengan menerapkan media audiovisual berupa

cuplikan film berbantuan pindai kode QR)

$\mathrm{O}=$ observasi

Data penelitian diperoleh dengan menggunakan instrumen penelitian berupa tes dan nontes. Instrumen tes berupa tes formatif (pilihan ganda) atau merespon jawaban sebanyak sepuluh butir soal. Instrumen tes tersebut dikembangkan dengan pertanyaan yang termasuk ke dalam level 4, 5, dan 6 kateghori HOTS (Higher Order Thinking Skill).

Instrumen nontes berupa data ang-ket dengan bantuan aplikasi Google Form. Data hasil observasi penelitian berupa hasil prates dan pascates serta data hasil penyebaran angket.

Pengolahan data dilakukan dengan analisis statistik parametrik. Sebelum menerapkan media audiovisual berbentuk cuplikan film, penulis mela-kukan uji analisis terhadap media tersebut. Namun, sebelum mengolah menggunakan analisis parametrik data tersebut diuji normalitas serta homogenitasnya. Apabila data tersebut berdistribusi normal dan homogen, selanjutnya penulis melakukan analisis parametrik untuk melakukan uji kore lasi serta uji hipotesis. Adapun hipotesis $\left(\mathrm{H}_{\mathrm{a}}\right)$ yang diajukan dalam penelitian ini adalah terdapat perbedaan yang signifikan dalam hasil belajar peserta didik dalam pembelajaran teks biografi kelas X SMK Negeri 1 Simpang Rimba, sebelum dan setelah diterapkan media cuplikan film berbantuan pindai kode QR.

\section{HASIL DAN PEMBAHASAN}

Penelitian ini dilakukan untuk melihat keefektifan penerapan media audiovisual dalam bentuk cuplikan film berbantuan pindai kode QR dalam pembelajaran teks biografi. Media tersebut telah dilakukan uji analisis oleh dua pakar yakni satu Guru Bahasa di SMK Negeri 1 Simpang Rimba serta satu Guru Bahasa di berbeda sekolah. Uji analisis tersebut dilakukan dalam bentuk pengajuan angket yang terdiri dari lima aspek penilaian, yakni aspek suara, aspek warna, aspek musik, aspek isi cerita, serta aspek format penyajian.

Hasil uji analisis tersebut menunjukkan bahwa media cuplikan film tersebut layak diterapkan dan sesuai dengan materi yang dilaksanakan dalam pembelajaran.

Hasil penelitian diperoleh dari observasi terhadap nilai prates dan nilai pascates. Setelah dilakukan prates dan dianalisis, nilai yang diperoleh masuk dalam kategori rendah, yakni rerata 53,73. Hal tersebut disebabkan oleh banyaknya peserta didik yang mengeluh mengenai teks yang disediakan seperti terlalu panjang dan ma-las untuk membacanya serta belum Sastrovariatifnya media a pembelajaran yang digunakan.

Nilai tertinggi prates yang diperoleh yaitu sebesar 70 dan nilai terendah yaitu sebesar 30. Setelah dilakukannya treatment, nilai tertinggi pascates yang diperoleh yaitu sebesar 100 dan nilai terendah yaitu sebesar 50. Adapun rerata nilai pascates ialah 77,73. Berdasarkan data tersebut, terlihat perbedaan nilai prates dan pascates. 
Setelah diperoleh data tersebut, dilakukan uji normalitas dan uji homogenitas. Data prates-pascates tersebut berdistribusi normal dan homogen, maka dari itu dilanjutkan dengan penghitungan uji korelasi serta uji hipotesis. Uji hipotesis dilakukan untuk melihat perbedaan yang signifikan untuk menyatakan efektif tidaknya media cuplikan film berbantuan pindai kode QR dalam pembelajaran teks biografi.

Uji hipotesis dilakukan dengan menggunakan uji-t. Berdasarkan perhitungan menggunakan uji-t dengan membandingkan nilai rerata prates dan pascates, hasilnya menunjukkan bahwa $\mathrm{t}_{\text {hitung }} \geq \mathrm{t}_{\text {tabel }}$ atau 3,733 1,71088. Yang berarti $\mathrm{H}_{\mathrm{o}}$ ditolak dan $\mathrm{H}_{\mathrm{a}}$ diterima, atau dengan kata lain terdapat perbedaan yang signifikan dalam hasil belajar peserta didik dalam pembelajaran teks biografi kelas X SMK Negeri 1 Simpang Rimba, sebelum dan setelah diterapkan media cuplikan film berbantuan pindai kode QR. Adapun grafik untuk menunjukkan perbedaan nilai ratarata prates-pascates adalah sebagai beri-kut.

\section{Grafik Rata-Rata Nilai Prates-Pascates}

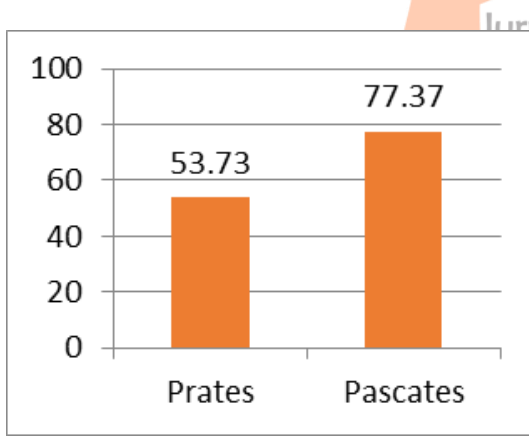

Adapun hasil anallisis instrumen nontes berupa angket disebarkan dan dianalisis menggunakan bantuan aplikasi Google Form. Angket tersebut berisi mengenai pertanyaan terhadap kondisi yang dirasakan peserta didik setelah mengikuti pembelajaran dengan menggunakan media audiovisual dalam bentuk cuplikan film berbantuan pindai kode QR.

Berdasarkan perhitungan, diperoleh data observasi dalam bentuk nilai prates dan pascates setelah diberikan perlakuan. Terdapat padanya peningkatan dari rerata hasil nilai prates dan pascates tersebut. Sebelum adanya pe-nerapan media cuplikan film berbantuan pindai kode QR, kemampuan peserta didik dalam memahami teks biografi sangat kurang. Itu terlihat dari perolehan nilai rerata prates yang rendah. Hal tersebut disebabkan oleh rasa bosan dalam membaca wacana sulitnya dalam memahami wacana, sehingga menyulitkan peserta didik dalam menjawab pertanyaan yang tepat.

Pada saat kegiatan perlakuan dengan menerapkan media cuplikan film berbantuan pindai kode QR, peserta didik dilatih untuk berpikir kritis terhadap materi yang disampaikan. Peserta didik diberikan rangsangan berupa pertanyaan-pertanyaan sebagai kegiatan untuk menggali didikan Prior knowledge nya.
onesia dan DTujuan dari penerapan media cuplikan film berbantuan pindai kode QR ini yaitu untuk membangun peserta didik agar terbiasa dalam berpikir kritis dengan menggunakan pendekatan saintifik, kolaboratif (belajar berkelompok), dan pertanyaan evaluasi yang termasuk dalam kategori level HOTS. Sesuai dengan tujuannya, ternyata dengan diterapkannya media tersebut dapat 
kemampuan peserta didik dalam memahami teks biografi dan muali dengan berpikir kritis.

Selain itu, dengan adanya kegiatan berkelompok hal tersebut perlu dilakukan untuk melibatkan peserta didik secara aktif karena peserta didik tidak dituntut untuk sekadar memahani materi dalam cuplikan film saja.

Terdapat perbedaan yang signifikan antara rerata nilai prates dan pascates. Hal tersebut terbukti dengan uj hipotesis yang hasilnya menunjukkan bahwa harga $t_{\text {hitung }}>t_{\text {tabel }}$ yaitu 3,733 $\geq 1,71088$, yang artinya $H_{a}$ diterima.

Jadi, kesimpulannya terdapat perbedaan yang signifikan dalam hasil belajar peserta didik dalam pembelajaran teks biografi kelas X SMK Negeri 1 Simpang Rimba, sebelum dan setelah diterapkan media cuplikan film berbantuan pindai kode QR dan dapat meningkatkan hasil belajar peserta didik.

Peningkatan nilai peserta didik tidak secara otomatis diperoleh peserta didik. melainkan, melalui proses yang cukup dalam kegiatan perlakuan. Dengan tahap-tahap yang terdapat dalam pembelajaran, penerapan media cuplikan film berbantuan pindai kode QR dapat menjadikan nilai memahami teks biografi mengalami perbedaan yangidikiah biografi mengalami perbedaan yangidikan Bah graf, 5 asebelum diberi perlakuan signifikan. Seperti yang terdapatesia dan Dsebesar 53,73.

dalam teori, bahwa media pembelajaran dapat meningkatkan dan mengarahkan motivasi peserta didik dalam belajar sehingga dapat mengoptimalkan yang dipelajari.

Oleh sebab itu, media cuplikan film berbantuan pindai kode QR dapat digunakan sebagai alternatif sekaligus inovatif dalam pembelajaran memahami teks biografi karena terbukti efektif meningkatkan kemampuan peserta didik dalam memahami teks biografi serta dapat meningkatkan daya berpikir kritis peserta didik.

Instrumen nontes berupa angket yang disebar dengan bantuan Google Form, penulis sebarkan dalam bentuk kegiatan silang pendapat sebagai bentuk refleksi terhadap pembelajaran yang telah diikuti.

Berdasarkan hasil analisis silang pendapat tersebut, jawaban peserta didik menunjukkan respon positif seperti, pembelajaran yang menyenangkan, mempermudah dalam memahami materi, tahapan yang dilalui mudah diikuti, tidak membosankan, dan membuat nilai mereka meningkat. Dengan demikian, berdasarkan bukti hasil jawaban angket tersebut peserta didik menunjukkan banyak respons positif terhadap pembelajaran terse-but.

\section{PENUTUP}

\section{Simpulan}

Simpulan yang diperoleh dari hasil penelitian ini adalah sebagai berikut.

1) Nilai rerata kemampuan peserta didik dalam memahami teks biodidik diberi perlakuan

2) Nilai rerata kemampuan peserta didik dalam memahami teks biografi setelah diberi perlakuan berupa penerapan media cuplikan film berbantuan pindai kode QR sebesar 53,73.

3) Berdasarkan perhitungan pembuktian hipotesis dengan $\mathrm{dk}=24$ dan taraf kepercayaan $95 \%$, diketahui bahwa harga $t_{\text {hitung }}$ lebih 
besar dari $t_{\text {tabel }}$ yaitu $3,733 \geq$ 1,71088. Artinya, $\mathrm{H}_{\mathrm{a}}$ diterima dan $\mathrm{H}_{0}$ ditolak. Adapun $\mathrm{H}_{\mathrm{a}}$ yaitu terdapat perbedaan yang signifikan dalam hasil belajar peserta didik dalam pembelajaran teks biografi kelas X SMK Negeri 1 Simpang Rimba, sebelum dan setelah diterapkan media cuplikan film berbantuan pindai kode QR.

4) Berdasarkan pembuktian hipotesis, media cuplikan film berbantuan pindai kode QR efektif dalam meningkatkan kemampuan peserta didik dalam memahami teks biografi. Penerapan media tersebut mampu merangsang serta meningkatkan daya berpikir kritis peserta didik. Selain itu, dengan meningkatnya hasil belajar peserta didik menunjukkan dapat menjawab pertanyaan HOTS dengan rerata tepat.

5) Berdasarkan hasil analisis silang pendapat tersebut, jawaban peserta didik menunjukkan respons positif seperti, pembelajaran yang menyenangkan, mempermudah dalam memahami materi, tahapan yang dilalui mudah diikuti, tidak membosankan, dan membuat nilai mereka meningkat.

\section{DAFTAR PUSTAKA}

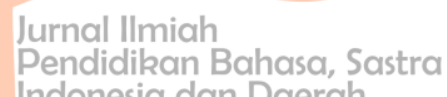

daring] https://files.eric.ed.gov. [21 September 2018].

Depdikbud. 2016. Silabus Mata Pelajaran SMA/SMK/MA Bahasa Indonesia. Jakarta: Depdikbud.

Hosnan. 2014. Pendekatan Saintifik dan Kontekstual dalam Pembelajaran Abad 21. Bogor: Ghalia Indonesia.

Kurniasih, Imas, dkk. 2014. Sukses Mengimplementasikan Kurikulum 2013. Jakarta: Kata Pena.

Pohl, Michael. 2000. Learning to Think and Thinking to Learning. Melbourne: Hawker Brownlow Education Pty Ltd.

Sugiyono. 2012. Metode Penelitian Kuantitatif Kualitatif dan $R \& D$. Bandung: Alfabeta.

Arikunto, Suharsimi. 2012. Dasar-

Dasar Evaluasi Pendidikan. Jakarta: Bumi Aksara. Azhar Arsyad. 2003. Media Pembelajaran. Jakarta: PT Raja Grafindo Persada.

Crompton, Hellen, dkk. 2012. QR Codes 101. Learning and Leading Technology. [Tersedia 